BMJ Open

Diabetes

Research

\& Care

\title{
Risk factors for new-onset diabetes mellitus after distal pancreatectomy
}

Menghua Dai (D , , ${ }^{1,2}$ Cheng Xing, ${ }^{1,2}$ Ning Shi, ${ }^{3}$ Shunda Wang, ${ }^{1,2}$ Guangdong Wu, ${ }^{1,2}$ Quan Liao, ${ }^{1,2}$ Taiping Zhang, ${ }^{1,2}$ Ge Chen, ${ }^{1,2}$ Wenming Wu, ${ }^{1,2}$ Junchao Guo, ${ }^{1,2}$ Ziwen Liu ${ }^{1,2}$

\section{ABSTRACT}

Shi N, et al. Risk factors for new-onset diabetes mellitus after distal pancreatectomy. BMJ Open Diab Res Care 2020;8:e01778. doi:10.1136/ bmjdrc-2020-001778

- Supplemental material is published online only. To view, please visit the journal online (http://dx.doi.org/10.1136/ bmjdrc-2020-001778).

MD, CX and NS contributed equally.

Received 17 July 2020 Revised 24 September 2020 Accepted 28 September 2020

Check for updates

\section{(C) Author(s) (or their} employer(s)) 2020. Re-use permitted under CC BY-NC. No commercial re-use. See rights and permissions. Published by BMJ.

\section{${ }^{1}$ Department of General}

Surgery, Peking Union Medical College Hospital (PUMCH), Peking Union Medical College \& Chinese Academy of Medical Sciences, Beijing, China ${ }^{2}$ National Translational Medicine of China, Beijing, China

${ }^{3}$ Department of General Surgery, Guangdong Provincial People's Hospital, Guangdong Academy of Medical Sciences, Guangzhou, China

Correspondence to Dr Menghua Dai; daimh@pumch.cn was NODM.
Introduction Several previous studies have reported the incidence of new-onset diabetes mellitus (NODM) after pancreatectomy. Nevertheless, the results were inconsistent. The true rate of NODM after distal pancreatectomy (DP) is still unknown.

Research design and methods The aim of this study was to investigate the incidence of and the risk factors for NODM after DP. This study enrolled patients who underwent DP between January 2004 and February 2016 at Peking Union Medical College Hospital. Patients with preoperative diabetes mellitus or diagnosed with pancreatic cancer were excluded. The primary outcome

Results A total of 485 patients were enrolled. The median (IQR) of follow-up duration was 30.95 (9.26-180.30) months. The accumulative incidence of NODM was $8.9 \%$ at postoperative 6 months, $14.0 \%$ at postoperative year one, $22.3 \%$ at year three, $27.1 \%$ at year five, and $35.5 \%$ at year ten. Multivariate analysis showed that the risk of postoperative NODM was positively correlated with age (HR 1.029 (1.013-1.045), $p<0.001)$, preoperative body mass index (BMI) (HR 1.042 (1.003-1.083), $p=0.001)$, operative blood loss (HR 1.0003 (1.0002-1.0010), $p<0.001)$, and length of resected pancreas (HR 1.079 (1.013-1.148), $\mathrm{p}=0.017)$. Moreover, concomitant splenectomy (HR 2.001 (1.202-3.331), $\mathrm{p}=0.008$ ) was associated with significantly higher risk of postoperative NODM.

Conclusion NODM incidence increased with postoperative time progression. Age, BMI, surgical blood loss, length of resected pancreas and splenectomy were independent risk factors for NODM after DP.

Trial registration number NCT03030209.

\section{INTRODUCTION}

Distal pancreatectomy (DP), with or without splenectomy, has been considered the standard procedure for removal of lesions located in the body or tail of the pancreas. Today, the procedure is increasingly used, as the more frequent use of modern imaging studies often reveals asymptomatic and frequently benign pancreatic lesions, such as intrapancreatic mucinous neoplasms, which are often situated in the pancreatic body or tail. ${ }^{1}$ As a result of the more benign nature of resected lesions, life expectancy after DP has increased, which places patients at risk for long-term

\section{Significance of this study}

What is already known about this subject?

- Patients who underwent distal pancreatectomy (DP) were more likely to develop new-onset diabetes mellitus (NODM), as compared with the patients who underwent pancreaticoduodenectomy. The incidence of NODM was significantly associated with pre-existing diseases, higher age, body mass index (BMI) and operative blood loss.

What are the new findings?

- NODM incidence increased with postoperative time progression. Age, BMI, surgical blood loss, length of resected pancreas and splenectomy were independent risk factors for NODM after DP. Our study was the first large cohort study validating the association between splenectomy and the development of NODM after DP.

How might these results change the focus of research or clinical practice?

- Our findings allow us to select patients with high risk for NODM and design more stringent surveillance and follow-up schedules for them. Early intervention and intensive glucose control have been reported to decrease the risks of major cardiovascular events and death in patients newly diagnosed with diabetes.

sequelae of pancreatectomy. Among these long-term complications, postoperative newonset diabetes mellitus (NODM) is a concern. Nevertheless, the true rate of NODM after DP is still unknown.

Postoperative NODM is one of the pancreatogenic diabetes conditions historically referred to as type $3 \mathrm{c}$ diabetes mellitus (DM). It is defined as diabetes caused by the loss or destruction of the pancreatic endocrine parenchyma. ${ }^{2}$ The endocrine parenchyma of the pancreas is scattered throughout the gland and is organized in clusters of cells forming islets of Langerhans. Four principal cell types make up the endocrine parenchyma: the insulin-producing $\beta$-islet cells, the glucagon-producing alpha cells, the pancreatic polypeptide-producing (PP) cells, 
and the somatostatin-producing delta cells. Because the insulin-producing $\beta$-islet cells are concentrated in the body and tail of the pancreas, ${ }^{3}$ long-term disturbance in glucose metabolism may be a prevalent sequela after DP.

Previous studies have found that postoperative diabetes develops in $9 \%-38 \%$ of patients after DP. ${ }^{4-12}$ Several studies $^{7-11}$ identified female sex, a high pancreatic resected ratio, a high body mass index (BMI), old age, and high preoperative hemoglobin $\mathrm{Alc}$ as independent risk factors for development of NODM after DP. However, several methodological limitations existed in these previous studies: the sample sizes of these studies were often small; few studies assessed the incidence of NODM along with follow-up time; few studies reported the incidence of NODM according to different types of pancreatectomy, such as pancreaticoduodenectomy, DP, and middle pancreatectomy, respectively; and length of follow-up was often missing.

The aim of the present study was to obtain exact incidence of NODM along with the follow-up progression and identify risk factors for the development of NODM after DP. Data were obtained through a large cohort of patients who underwent DP at a single tertiary referral hospital.

\section{METHODS}

\section{Study design and participants}

This was a cohort analysis using data from a dedicated pancreatectomy database prospectively maintained by the Pancreatic Surgical Center, Peking Union Medical College Hospital. Clinical data, pathological details and long-term follow-up outcomes were extracted. All enrolled patients signed the written informed consent. From 1 January 2004 to 13 February 2016, patients were considered eligible for this study if they underwent DP with or without splenectomy for a pancreatic lesion. Patients with preoperative DM and those pathologically diagnosed with pancreatic duct adenocarcinoma, acinar carcinoma, or pancreatic secondary malignant tumor were excluded. The criteria of preoperative or postoperative DM were referenced by the American Diabetes Association 2017 diagnostic criteria. ${ }^{13}$

\section{Operative technique}

These operations were performed by seven experienced surgeons in our department. The surgical procedures were standardized in our institution and the surgeons had received the same training. For open approach, the patient was placed in a supine position and a midline incision was used. For minimally invasive approach, the patient was placed in a reverse Trendelenburg position with legs apart. After creation of a carbon dioxide pneumoperitoneum via a $10 \mathrm{~mm}$ infraumbilical port, a $12 \mathrm{~mm}$ trocar and a $5 \mathrm{~mm}$ trocar were inserted at the left mid-clavicular line at umbilical level and $3 \mathrm{~cm}$ right of the umbilicus for the surgeon; another $5 \mathrm{~mm}$ trocar was placed in the left subcostal area for the assistant.
The operative procedure for both open and minimally invasive approach was similar. First, division of gastrocolic ligament was performed, from the midline towards the spleen to expose the isthmus, body, and tail of the pancreas. With the stomach elevated, the retroperitoneum was opened along the inferior pancreatic border and further dissection was performed on the avascular plane posterior to the pancreas until the splenic vein and artery were identified. Tunneling behind the pancreas neck was done and the neck of pancreas was dissected by using linear stapler. After dividing the neck of the pancreas, the splenic vein and splenic artery were ligated and divided. The short gastric vessels were ligated to mobilize the spleen and the specimen was retrieved. If the spleen was preserved, the Warshaw ${ }^{14}$ or Kimura ${ }^{15}$ technique would be performed, which was also described in our previous study. ${ }^{16}$

\section{Outcome measures}

The primary outcome was NODM. The American Diabetes Association 2017 diagnostic criteria ${ }^{13}$ for DM were adapted in the present study. In patients with classic symptoms of hyperglycemia or hyperglycemic crisis, a random plasma glucose (PG) level of $\geq 200 \mathrm{mg} / \mathrm{dL}$ (11.1 $\mathrm{mmol} / \mathrm{L}$ ) was sufficient for diagnosis of DM. In patients without unequivocal hyperglycemia, the following criteria were required to be confirmed on at least two occasions: (A) fasting plasma glucose (FPG; fasting is defined as no caloric intake for at least 8 hours $) \geq 126 \mathrm{mg} / \mathrm{dL}(7.0$ $\mathrm{mmol} / \mathrm{L})$; (B) 2-hour PG $\geq 200 \mathrm{mg} / \mathrm{dL}(11.1 \mathrm{mmol} / \mathrm{L})$ during an oral glucose tolerance test (OGTT; the test should be performed as described by the WHO, using a glucose load containing the equivalent of $75 \mathrm{~g}$ anhydrous glucose dissolved in water); or (C) HbAlc $\geq 6.5 \%$ ( $48 \mathrm{mmol} / \mathrm{mol}$ ).

Demographic characteristics included age, gender, American Society of Anesthesiologists (ASA) score, BMI, and family history of diabetes in first-degree relatives. Pathological data were extracted from the gross and microscopic examination of resected specimens, including tumor location, tumor component (cystic or solid), tumor size, length of resected pancreas, and pathological diagnosis. Length of resected pancreas was defined as the longitudinal distance between the pancreatic stump and the tip of the pancreatic tail (online supplemental figure 1). Tumor location was identified as the tail of the pancreas, when the left side of the tumor reached the tip of pancreatic tail or the tumor was between the pancreatic tail and the splenic hilum.

Surgery-related outcomes included operative time, estimated blood loss, preservation of spleen, preservation of splenic vessels, intraoperative splenic infarction and length of postoperative hospital stay.

Morbidity was defined as a complication occurring during the hospital stay or within 90 postoperative days, graded using the Clavien-Dindo system. ${ }^{17}$ Postoperative pancreatic fistula was evaluated using International Study Group of Pancreatic Fistula definition with clinical 
grading system (A, B, C) ${ }^{18}$ Abdominal abscess or infection was described in our previous study. ${ }^{16}$ Mortality was defined as surgery-related death within 90 days after the procedure.

\section{Follow-up}

Patients with benign and low-grade malignant pancreatic lesions who underwent DP in our institution were scheduled for outpatient follow-up at 1 month, 6 months, and 1 year after surgery. Thereafter, patients are followed every 6 months by outpatient service or telephone. In every follow-up, patients were scheduled to undergo FPG, HbAlc, routine blood examination, liver function tests, and renal function tests. If there were positive findings in FPG or HbAlc, patients were scheduled to undergo OGTT and were transferred to an endocrinologist. Follow-up duration was defined as the interval from the initial DP to the diagnosis of NODM or, in cases without DM onset, to the most recent follow-up visit.

\section{Statistical analyses}

Quantitative variables were expressed as the mean $\pm \mathrm{SD}$ or the median (IQR). Qualitative variables were expressed as a percentage. A Student's t-test or Mann-Whitney test was used for comparisons of quantitative variables, whereas a $\chi^{2}$ test or Fisher's exact test was used for comparisons of categorical data.

Survival distributions were estimated using the KaplanMeier method and compared using a log-rank test. Univariate and multivariate Cox proportional hazards models were employed to investigate risk factors for NODM and to compute HRs and their 95\% CIs. All of the variables that differed in the univariate Cox regression analysis with a $p$ value $<0.10$ were included in the multivariate Cox model with backward selection. The optimal cut-offs of risk factors for predicting the occurrence of postoperative NODM were estimated using receiver operating characteristic (ROC) curves. All tests were two sided. The threshold for statistical significance was set to $\mathrm{p}<0.05$. All statistical analyses were performed using SPSS V.19 (IBM).

\section{RESULTS}

\section{Participant characteristics}

After excluding other type of pancreatectomy, that is, pancreaticoduodenectomy $(\mathrm{n}=1204)$, central pancreatectomy $(\mathrm{n}=115)$, enucleation $(\mathrm{n}=586)$, and total pancreatectomy $(n=21), 840$ patients undergoing DP were identified from 1 January 2004 to 13 February 2016. Sixty-three patients with preoperative DM, 270 patients diagnosed with ductal adenocarcinoma, 6 patients diagnosed with acinar carcinoma, and 16 patients diagnosed with pancreatic metastatic cancer were excluded, according to prespecified criteria (figure 1A). Finally, 485 patients were enrolled in the present study. Eighty-one patients $(16.7 \%)$ were lost to follow-up. Median (IQR) of follow-up duration was 30.95 (9.26-180.30) months.

The demographic characteristics and pathological details of included patients are summarized in table 1 .

The mean age was $44.37 \pm 15.14$ years; $349(72 \%)$ patients were female; $22(4.5 \%)$ patients had a family history of diabetes (first-degree relatives). The mean BMI was $23.37 \pm 3.85 \mathrm{~kg} / \mathrm{m}^{2}$. Patients with the ASA scores of I and II accounted for $41.4 \%$ (201) and $55.7 \%$ (270), respectively. Pancreatic lesions of 336 (69.3\%) patients were located in either the neck or body. The components of pancreatic lesions were cystic in $200(41.4 \%)$ patients and solid in $183(37.7 \%)$ patients, respectively. The mean diameter of pancreatic lesions was $4.64 \pm 3.09 \mathrm{~cm}$, and the mean length of resected pancreas was $9.60 \pm 3.50 \mathrm{~cm}$. The

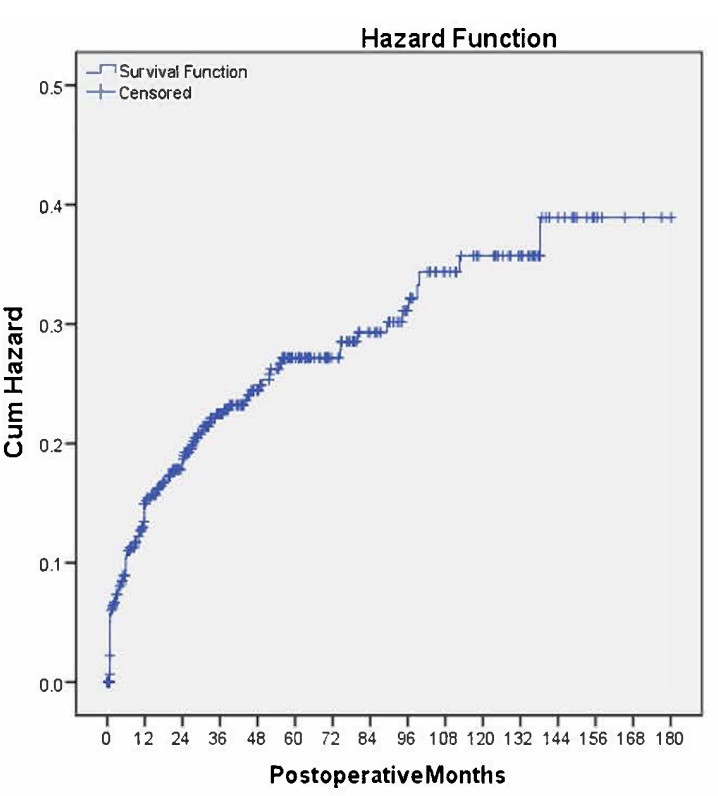


Table 1 Characteristics of included patients who develop and do not develop new-onset diabetes mellitus

\begin{tabular}{|c|c|c|c|c|}
\hline & \multirow{2}{*}{$\begin{array}{l}\text { Overall } \\
(\mathrm{n}=485)\end{array}$} & \multicolumn{3}{|c|}{ New-onset diabetes mellitus } \\
\hline & & Yes $(n=112)$ & No $(n=373)$ & $P$ value \\
\hline \multicolumn{5}{|c|}{ Demographic characteristics and pathological details } \\
\hline Age (years) & $44.37 \pm 15.14$ & $50.95 \pm 12.90$ & $42.39 \pm 15.22$ & $<0.001^{*}$ \\
\hline Gender, female & $349(72.0)$ & $69(61.6)$ & $280(75.1)$ & $0.005^{*}$ \\
\hline $\begin{array}{l}\text { Family history of diabetes (first- } \\
\text { degree relatives) }\end{array}$ & $22(4.5)$ & $4(3.6)$ & $18(4.8)$ & 0.576 \\
\hline Body mass index $\left(\mathrm{kg} / \mathrm{m}^{2}\right)$ & $23.37 \pm 3.85$ & $23.64 \pm 3.41$ & $23.02 \pm 3.91$ & $<0.001^{*}$ \\
\hline \multicolumn{5}{|l|}{ ASA score } \\
\hline 1 & $201(41.4)$ & $34(32.1)$ & $167(44.1)$ & $0.039^{*}$ \\
\hline II & $270(55.7)$ & $69(65.1)$ & $201(53.0)$ & \\
\hline III & $14(2.9)$ & $3(2.8)$ & $11(2.9)$ & \\
\hline Location of tumor & & & & $<0.001^{*}$ \\
\hline Neck or body & $336(69.3)$ & 94 (83.9) & $242(64.9)$ & \\
\hline Tail & $149(30.7)$ & $18(16.1)$ & $131(35.1)$ & \\
\hline Component of tumor & & & & 0.399 \\
\hline Cystic & $200(41.2)$ & $46(41.1)$ & $154(41.3)$ & \\
\hline Cystic and solid & $102(21.0)$ & $19(17.0)$ & $83(22.3)$ & \\
\hline Solid & $183(37.7)$ & $47(42.0)$ & $136(36.5)$ & \\
\hline Tumor size $(\mathrm{cm})$ & $4.64 \pm 3.09$ & $4.66 \pm 3.34$ & $4.65 \pm 3.02$ & 0.200 \\
\hline Length of resected pancreas $(\mathrm{cm})$ & $9.60 \pm 3.50$ & $10.71 \pm 3.66$ & $9.26 \pm 3.38$ & $<0.001^{*}$ \\
\hline Pathological diagnosis & & & & $0.011^{*}$ \\
\hline Serous cystic neoplasm & $85(17.5)$ & $18(16.1)$ & $67(18.0)$ & 0.644 \\
\hline Mucinous cystic neoplasm & $90(18.6)$ & $24(21.4)$ & $66(17.7)$ & 0.373 \\
\hline Neuroendocrine tumor & $129(26.6)$ & $34(30.4)$ & $95(25.5)$ & 0.305 \\
\hline Solid pseudopapillary neoplasm & $95(19.6)$ & $9(8.0)$ & $86(23.1)$ & $<0.001^{*}$ \\
\hline $\begin{array}{l}\text { Intraductal papillary mucinous } \\
\text { neoplasm }\end{array}$ & $27(5.6)$ & $11(9.8)$ & $16(4.3)$ & $0.025^{\star}$ \\
\hline Pseudocyst & $19(3.9)$ & $4(3.6)$ & $15(4.0)$ & 0.950 \\
\hline Chronic pancreatitis & $13(2.7)$ & $5(4.5)$ & $8(2.1)$ & 0.318 \\
\hline Other & $27(5.6)$ & $7(6.3)$ & $20(5.4)$ & 0.719 \\
\hline \multicolumn{5}{|c|}{ Operative and postoperative courses } \\
\hline Operative approach & & & & $0.001^{*}$ \\
\hline Minimally invasive approach & $211(43.5)$ & $34(30.4)$ & $177(47.5)$ & \\
\hline Open approach & $274(56.4)$ & $78(69.6)$ & $196(52.5)$ & \\
\hline Operative time (min) & $207.37 \pm 70.39$ & $220.92 \pm 70.33$ & $203.30 \pm 70.00$ & $0.021^{*}$ \\
\hline Operative blood loss (mL) & $435.63 \pm 668.60$ & $619.20 \pm 1085.93$ & $380.51 \pm 465.34$ & $0.001^{*}$ \\
\hline Splenic preservation & $189(39.0)$ & $23(20.5)$ & $166(44.5)$ & $<0.001^{*}$ \\
\hline $\begin{array}{l}\text { Splenic vessel preservation in } \\
\text { patients with splenic preservation }\end{array}$ & $95 / 189$ & $11 / 23(47.8)$ & $84 / 166(50.6)$ & 0.803 \\
\hline $\begin{array}{l}\text { Splenic infarction in patients with } \\
\text { splenic preservation }\end{array}$ & $18 / 189$ & $5 / 23(21.7)$ & 13/166 (7.8) & $0.033^{\star}$ \\
\hline Postoperative complication & $102(21.0)$ & $37(33.1)$ & $65(17.4)$ & $0.001^{*}$ \\
\hline Clavien-Dindo grades I-II & $90(18.6)$ & 35 (31.3) & $55(14.7)$ & \\
\hline Clavien-Dindo grades III-IV & $12(2.5)$ & $2(1.8)$ & $10(2.7)$ & \\
\hline $\begin{array}{l}\text { Clinical postoperative pancreatic } \\
\text { fistula (grades B and C) }\end{array}$ & $37(7.6)$ & $11(9.8)$ & $26(7.0)$ & 0.319 \\
\hline
\end{tabular}


Table 1 Continued

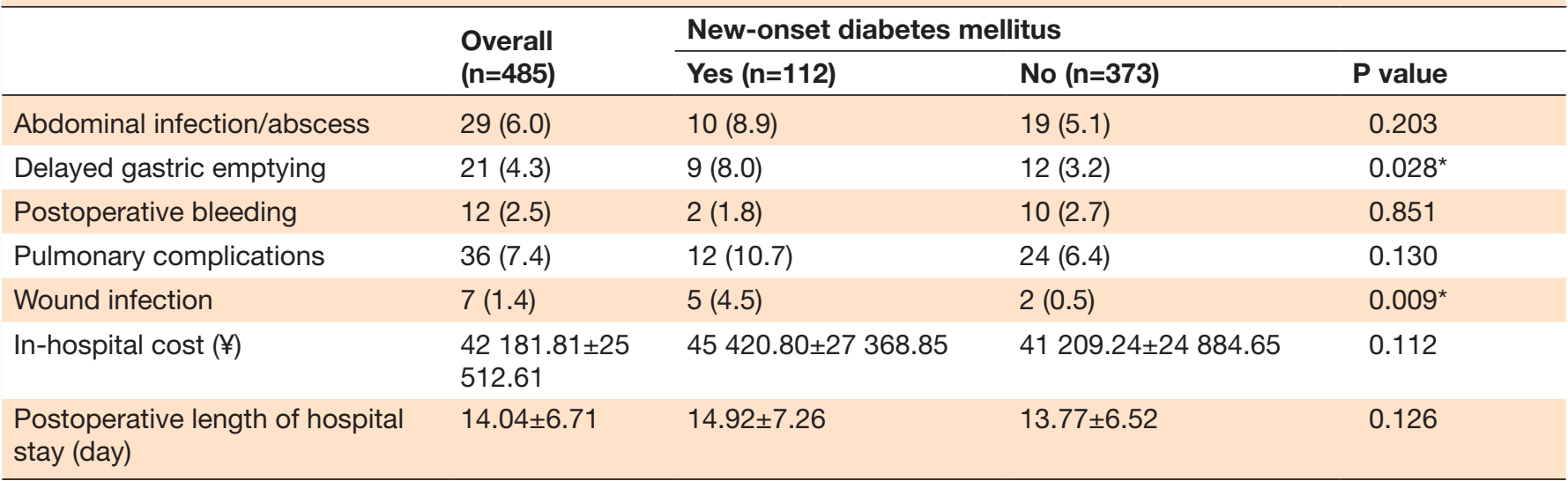

*Statistically significant.

ASA, American Society of Anesthesiologists.

most common pathological diagnoses were neuroendocrine tumor $(26.6 \%)$, solid pseudopapillary neoplasm $(19.6 \%)$, mucinous cystic neoplasm $(18.6 \%)$, and serous cystic neoplasm $(17.5 \%)$.

Table 1 also describes the operative and postoperative outcomes. More than 40 percentage of patients $(43.5 \%, \mathrm{n}=211)$ underwent minimally invasive surgery. The mean operative time was $207.37 \pm 70.39$ min with mean operative blood of $435.63 \pm 668.60 \mathrm{~mL}$. Among the $189(39.0 \%)$ patients who underwent spleenpreserving DP, 95 underwent splenic vessels preservation. With regard to postoperative courses, 90 (18.6\%) patients and $12(2.5 \%)$ patients suffered from complications of Clavien-Dindo grades I-II and III-IV, respectively. Less than $10 \%$ of patients suffered from clinical pancreatic fistula $(7.6 \%, \mathrm{n}=37)$ and abdominal infection $(6.0 \%, \mathrm{n}=29)$, respectively. Among those who underwent spleen-preserving DP, 18 patients had partial splenic infarction. The in-hospital cost and postoperative length of hospital stay of this cohort were $¥ 42181.81 \pm ¥ 25512.61$ and $14.04 \pm 6.71$ days.

Patients who develop NODM were identified by the following characteristics: older age $(50.95 \pm 12.90$ years, $\mathrm{p}<0.001)$, male $(38.4 \%, \mathrm{p}=0.005)$, higher $\mathrm{BMI}$ $(23.64 \pm 3.41, \mathrm{p}<0.001)$, tumor location of pancreatic neck or body $(83.9 \%, \mathrm{p}<0.001)$, longer length of resected pancreas $(10.71 \pm 3.66 \mathrm{~cm}, \mathrm{p}<0.001)$, specific pathological diagnosis (serous cystic neoplasm $16.1 \%$, mucinous cystic neoplasm 21.4\%, neuroendocrine tumor $30.4 \%$, solid pseudopapillary neoplasm $8.0 \%$, intraductal papillary mucinous neoplasm $9.8 \%$, pseudocyst $3.6 \%$, and chronic pancreatitis $4.5 \%$, $\mathrm{p}=0.011)$, open operative approach $(69.6 \%, \mathrm{p}=0.001)$, longer operative time $(220.92 \pm 70.33 \mathrm{p}=0.021)$, more operative blood loss $(619.20 \pm 1085.93 \mathrm{~mL}, \mathrm{p}=0.001)$, splenectomy $(79.5 \%, \mathrm{p}<0.001)$ or splenic infarction (21.7\%, $\mathrm{p}=0.033)$, and postoperative complications (33.1\%, $\mathrm{p}=0.001)$, compared with those who do not develop NODM (table 1).
Univariate and multivariate analyses of the development of postoperative NODM

Univariate Cox regression analysis investigated the relationship between the development of NODM and demographic characteristics, pathological details, operative and postoperative courses. Age $(\mathrm{p}<0.001)$, gender $(\mathrm{p}=0.007)$, BMI $(\mathrm{p}<0.001)$, ASA score (II; $\mathrm{p}=0.047)$, length of resected pancreas $(\mathrm{p}<0.001)$, pathological diagnosis (solid pseudopapillary neoplasm; $\mathrm{p}=0.003$ ), operative approaches $(\mathrm{p}=0.015)$, operative time $(\mathrm{p}=0.015)$, operative blood loss $(p<0.001)$, splenectomy $(p<0.001)$, and postoperative complication $(\mathrm{p}=0.002)$ were identified as statistically significant influential factors for postoperative NODM (table 2).

As the prespecified criteria, potential risk factors with $\mathrm{p}$ values $<0.10$ in the univariate analysis entered the multivariate Cox regression model. Age (HR 1.029 (1.013-1.045), $\mathrm{p}<0.001$ ), preoperative BMI (HR 1.042 (1.003-1.083), $\mathrm{p}=0.034)$, operative blood loss (HR 1.0003 (1.0002-1.0010), $\mathrm{p}=0.005)$, splenectomy (HR 2.001 (1.202-3.331), $\mathrm{p}=0.008)$, and length of resected pancreas (HR 1.079 (1.013-1.148), $\mathrm{p}=0.017$ ) were identified as independent risk factors for NODM (table 2).

\section{Incidence of postoperative NODM in different risk-stratified subgroups}

In this cohort, 112 patients suffered from NODM during the follow-up period. Specifically, in the actuarial estimate, rates of NODM were $8.9 \%$ at postoperative month six, $14.0 \%$ at postoperative year one, $17.9 \%$ at year two, $22.3 \%$ at year three, $27.1 \%$ at year five, and $35.5 \%$ at year ten (figure 1B).

\section{Age}

As an independent risk factor for postoperative NODM, the optimal cut-off of age was 38 years old determined by ROC curve. In patients under age 38 , postoperative rates of NODM were $1.2 \%$ at month six, $2.7 \%$ at year one, $5.0 \%$ at year two, $7.0 \%$ at year three, $9.7 \%$ at year five, 
Table 2 Univariate and multivariate Cox regression analysis of risk factors for postoperative NODM

\begin{tabular}{|c|c|c|c|c|c|}
\hline & \multicolumn{2}{|l|}{ Univariable model } & \multicolumn{2}{|l|}{ Multivariable model } & \multirow{2}{*}{$\begin{array}{l}\text { Cut-off } \\
\text { value }\end{array}$} \\
\hline & HR $(95 \% \mathrm{Cl})$ & $P$ value & HR $(95 \%$ Cl) & $P$ value & \\
\hline Age (years) & 1.037 (1.024 to 1.050$)$ & $<0.001^{*}$ & 1.029 (1.013 to 1.045$)$ & $<0.001$ & 38 \\
\hline Gender & & $0.007^{\star}$ & & & \\
\hline Male & $1.300(1.074$ to 1.573$)$ & & & & \\
\hline Female & Ref & & & & \\
\hline $\begin{array}{l}\text { Family history of type } 2 \text { diabetes } \\
\text { (first-degree relatives) }\end{array}$ & & 0.406 & & & \\
\hline Yes & 1.209 (0.772 to 1.894$)$ & & & & \\
\hline No & Ref & & & & \\
\hline Body mass index $\left(\mathrm{kg} / \mathrm{m}^{2}\right)$ & 1.067 (1.032 to 1.103$)$ & $<0.001^{*}$ & 1.042 (1.003 to 1.083$)$ & 0.034 & 23.47 \\
\hline ASA score & & $0.047^{\star}$ & & & \\
\hline I & Ref & & & & \\
\hline II & 1.640 (1.097 to 2.452$)$ & & & & \\
\hline III & 1.478 (0.452 to 4.832$)$ & & & & \\
\hline Component of tumor & & 0.741 & & & \\
\hline Cystic & 0.557 (0.362 to 0.857$)$ & & & & \\
\hline Cystic and solid & 0.718 (0.446 to 1.155$)$ & & & & \\
\hline Solid & Ref & & & & \\
\hline Tumor size $(\mathrm{cm})$ & 0.998 (0.938 to 1.063$)$ & 0.200 & & & \\
\hline Length of resected pancreas (cm) & 1.101 (1.051 to 1.153$)$ & $<0.001^{*}$ & 1.079 (1.013 to 1.148$)$ & 0.017 & 8.95 \\
\hline Pathological diagnosis & & $0.003^{*}$ & & & \\
\hline Serous cystic neoplasm & Ref & & & & \\
\hline Mucinous cystic neoplasm & 1.064 (0.577 to 1.962$)$ & & & & \\
\hline Neuroendocrine tumor & 1.089 (0.614 to 1.931$)$ & & & & \\
\hline Solid pseudopapillary neoplasm & 0.353 (0.158 to 0.787$)$ & & & & \\
\hline $\begin{array}{l}\text { Intraductal papillary mucinous } \\
\text { neoplasm }\end{array}$ & 2.148 (1.014 to 4.511$)$ & & & & \\
\hline Pseudocyst & 0.719 (0.238 to 2.170$)$ & & & & \\
\hline Chronic pancreatitis & 1.882 (0.698 to 5.073$)$ & & & & \\
\hline Other & 1.045 (0.428 to 2.548$)$ & & & & \\
\hline Operative approach & & $0.015^{\star}$ & & & \\
\hline Open & Ref & & & & \\
\hline Minimally invasive & 0.618 (0.419 to 0.911$)$ & & & & \\
\hline Operative time (min) & 1.003 (1.001 to 1.005$)$ & $0.015^{*}$ & & & \\
\hline Operative blood loss (mL) & 1.000 (1.000 to 1.001$)$ & $<0.001^{*}$ & 1.0003 (1.0002 to 1.0010$)$ & 0.005 & 425 \\
\hline Splenectomy & & $<0.001^{*}$ & & & \\
\hline Yes & 1.686 (1.335 to 2.130$)$ & & 2.001 (1.202 to 3.331$)$ & 0.008 & \\
\hline No & Ref & & & & \\
\hline Postoperative complication & & $0.002^{*}$ & & & \\
\hline Yes & 1.943 (1.309 to 2.884$)$ & & & & \\
\hline No & Ref & & & & \\
\hline $\begin{array}{l}\text { Clinical postoperative pancreatic } \\
\text { fistula (grades B and C) }\end{array}$ & & 0.213 & & & \\
\hline Yes & 1.482 (0.795 to 2.764$)$ & & & & \\
\hline No & Ref & & & & \\
\hline Abdominal infection/abscess & & 0.067 & & & \\
\hline
\end{tabular}


Table 2 Continued

\begin{tabular}{|c|c|c|c|c|c|}
\hline & \multicolumn{2}{|l|}{ Univariable model } & \multicolumn{2}{|c|}{ Multivariable model } & \multirow{2}{*}{$\begin{array}{l}\text { Cut-off } \\
\text { value }\end{array}$} \\
\hline & HR (95\% Cl) & $P$ value & HR (95\% Cl) & $P$ value & \\
\hline Yes & 1.942 (1.013 to 3.723$)$ & & & & \\
\hline No & Ref & & & & \\
\hline In-hospital cost ( $)$ & 1.000 (1.000 to 1.000$)$ & 0.053 & & & \\
\hline $\begin{array}{l}\text { Postoperative length of hospital stay } \\
\text { (day) }\end{array}$ & $1.020(0.996$ to 1.044$)$ & 0.110 & & & \\
\hline
\end{tabular}

*Statistically significant.

ASA, American Society of Anesthesiologists; NODM, new-onset diabetes mellitus.

and $17.4 \%$ at year ten. In patients over age 38 , the postoperative rates of NODM were $13.0 \%$ in postoperative month six, $19.9 \%$ at year one, $24.6 \%$ at year two, $30.2 \%$ at year three, $35.9 \%$ at year five, and $44.8 \%$ at year ten $(\mathrm{p}<0.001)$ (table 3 and figure $2 \mathrm{~A})$.

\section{Preoperative BMI}

Preoperative BMI was qualified as an independent risk factor for development of NODM ( $\mathrm{p}=0.034) ; 23.47 \mathrm{~kg} /$ $\mathrm{m}^{2}$ was determined to be the optimally predictive cut-off. In patients with BMI $\leq 23.47 \mathrm{~kg} / \mathrm{m}^{2}$, postoperative incidence of NODM was $5.3 \%$ at month six, $7.4 \%$ at year one, 9.2\% at year two, $11.4 \%$ at year three, $15.8 \%$ at year five, and $26.6 \%$ at year ten. Among patients with BMI $>23.47$ $\mathrm{kg} / \mathrm{m}^{2}$, the postoperative incidence of NODM was $13.8 \%$ at month six, $22.9 \%$ at year one, $29.8 \%$ at year two, $37.2 \%$ at year three, $42.6 \%$ at year five, and $47.5 \%$ at year ten $(\mathrm{p}<0.001)$ (table 3 and figure 2B).

\section{Operative blood loss}

Operative blood loss was positively correlated with the rate of postoperative NODM ( $\mathrm{p}=0.005) ; 425 \mathrm{~mL}$ was determined to be the optimally predictive cut-off. In patients with blood loss $\leq 425 \mathrm{~mL}$, postoperative incidence of NODM was $6.6 \%$ at month six, $11.8 \%$ at year one, $13.7 \%$ at year two, $16.4 \%$ at year three, $20.4 \%$ at year five, and $28.0 \%$ at year ten. Among patients with blood loss $>425 \mathrm{~mL}$, the postoperative incidence of NODM was $14.1 \%$ at month six, $18.8 \%$ at year one, $26.4 \%$ at year two, $34.4 \%$ at year three, $40.7 \%$ at year five, and $49.7 \%$ at year ten $(\mathrm{p}<0.001)$ (table 3 and figure $2 \mathrm{C}$ ).

\section{Length of resected pancreas}

Longer resected pancreas was associated with higher risk for development of NODM $(\mathrm{p}=0.017)$. The optimal cut-off was $8.95 \mathrm{~cm}$. In patients with a length of resected pancreas $\leq 8.95 \mathrm{~cm}$, postoperative incidence of NODM

\begin{tabular}{|c|c|c|c|c|c|c|c|}
\hline Risk factor & $\begin{array}{l}0.5 \text { year } \\
(\%)\end{array}$ & $\begin{array}{l}1 \text { year } \\
(\%)\end{array}$ & $\begin{array}{l}2 \text { years } \\
\text { (\%) }\end{array}$ & $\begin{array}{l}3 \text { years } \\
(\%)\end{array}$ & $\begin{array}{l}5 \text { years } \\
(\%)\end{array}$ & $\begin{array}{l}10 \text { years } \\
(\%)\end{array}$ & P value* \\
\hline \multicolumn{8}{|l|}{ Age (years) } \\
\hline$\leq 38(n=168)$ & 1.2 & 2.7 & 5.0 & 7.0 & 9.7 & 17.4 & $<0.001$ \\
\hline$>38(n=317)$ & 13.0 & 19.9 & 24.6 & 30.2 & 35.9 & 44.8 & \\
\hline \multicolumn{8}{|l|}{ BMI $\left(\mathrm{kg} / \mathrm{m}^{2}\right)$} \\
\hline$\leq 23.47(n=277)$ & 5.3 & 7.4 & 9.2 & 11.4 & 15.8 & 26.6 & $<0.001$ \\
\hline$>23.47(n=208)$ & 13.8 & 22.9 & 29.8 & 37.2 & 42.6 & 47.5 & \\
\hline \multicolumn{8}{|c|}{ Operative blood loss (mL) } \\
\hline$\leq 425(n=332)$ & 6.6 & 11.8 & 13.7 & 16.4 & 20.4 & 28.0 & $<0.001$ \\
\hline$>425(n=153)$ & 14.1 & 18.8 & 26.4 & 34.4 & 40.7 & 49.7 & \\
\hline \multicolumn{8}{|l|}{ Splenectomy } \\
\hline Yes $(n=296)$ & 12.5 & 19.1 & 23.0 & 28.6 & 33.7 & 44.3 & $<0.001$ \\
\hline No $(n=189)$ & 3.4 & 5.8 & 9.2 & 11.7 & 15.6 & 18.6 & \\
\hline \multicolumn{8}{|c|}{ Length of resected pancreas $(\mathrm{cm})$} \\
\hline$\leq 8.95(n=207)$ & 4.7 & 7.6 & 9.4 & 11.0 & 15.4 & 21.6 & $<0.001$ \\
\hline$>8.95(n=278)$ & 12.0 & 18.5 & 24.0 & 30.4 & 35.4 & 45.6 & \\
\hline
\end{tabular}

*Log-rank test.

BMI, body mass index; NODM, new-onset diabetes mellitus. 

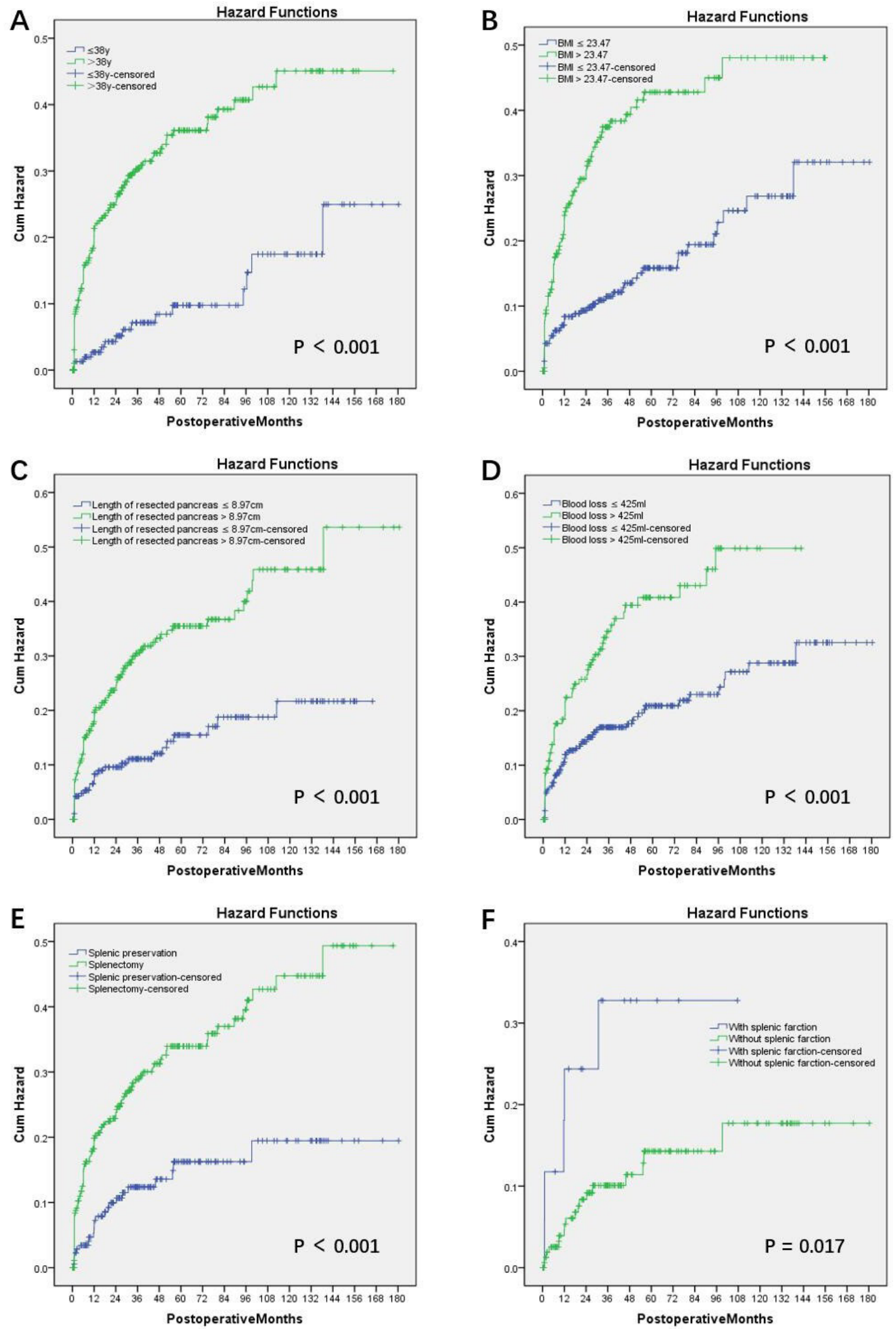

Figure 2 The incidences of new-onset diabetes mellitus (NODM) were significantly different between two comparative groups divided by the independent risk factors: age (A), preoperative BMI (B), length of resected pancreas (C), surgical blood loss (D), and splenectomy (E). The incidences of NODM were significantly different between patients with and without splenic infarction (F). BMI, body mass index. 
was $4.7 \%$ at month six, $7.6 \%$ at year one, $9.4 \%$ at year two, $11.0 \%$ at year three, $15.4 \%$ at year five, and $21.6 \%$ at year ten. Among patients with length of resected pancreas $>8.95 \mathrm{~cm}$, the postoperative incidence of NODM was $12.0 \%$ at month six, $18.5 \%$ at year one, $24.0 \%$ at year two, $30.4 \%$ at year three, $35.4 \%$ at year five, and $45.6 \%$ at year ten $(\mathrm{p}<0.001)$ (table 3 and figure 2D).

\section{Splenectomy}

Concomitant splenectomy was associated with significantly higher risk of postoperative NODM $(p=0.008)$. In patients with splenic preservation, postoperative incidence of NODM was $3.4 \%$ at month six, $5.8 \%$ at year one, $9.2 \%$ at year two, $11.7 \%$ at year three, $15.6 \%$ at year five, and $18.6 \%$ at year ten. Among patients with splenectomy, the postoperative incidence of NODM was $12.5 \%$ at month six, $19.1 \%$ at year one, $23.0 \%$ at year two, $28.6 \%$ at year three, $33.7 \%$ at year five, and $44.3 \%$ at year ten $(\mathrm{p}<0.001)$ (table 3 and figure $2 \mathrm{E})$.

Among patients with splenic preservation, there was no significant difference in risk of postoperative NODM between patients with splenic vessel preservation (Kimura method) and patients with splenic vessel resection (Warshaw method). However, partial splenic infarction was associated with increased risk of postoperative NODM, compared with patients with sufficient splenic blood perfusion ( $\mathrm{p}=0.017$; figure $2 \mathrm{~F}$ ).

\section{DISCUSSION}

Endocrine insufficiency is a highlighted long-term sequela after pancreatectomy. Several previous studies have reported the incidence of postpancreatectomy NODM, although the results were varied and inconsistent. Different length of follow-up period after pancreatectomy is one possible explanation for the different rates of NODM. The design of the present study allowed us to display a gradually increasing rate of postoperative NODM along with time progression. Such time-dependent data have rarely been demonstrated previously. These results provided an actual and specific profile of postoperative NODM after DP. The aim of this study was just designed to enroll patients with benign or low-grade malignant tumors in the pancreas because patients with pancreatic cancer often had a very short survival after operation. As a result, we can achieve longterm follow-up and good long-term survival rate and can study the rate of NODM after DP with time progression, even up to 10 years.

Several previous studies ${ }^{5} 9101920$ analyzed different types of pancreatectomy, such as pancreaticoduodenectomy, DP, and middle pancreatectomy, in the same group of patients. This approach may also contribute to the differing rates of postpancreatectomy NODM. Burkhart et $a l^{10}$ reported that patients who underwent DP were more likely to develop NODM, as compared with the pancreaticoduodenectomy group. These findings may be related to the asymmetric distribution of $\beta$-islet cells, which predominate in the body and tail of the pancreas, throughout the gland. In the current study, we included only patients undergoing DP, to diminish the heterogeneity of different operative types.

A previous systematic review by De Bruijn and van Eijck showed that the incidence of NODM was significantly associated with pre-existing diseases, from chronic pancreatitis to benign or (potentially) malignant lesions. ${ }^{21}$ In the present study, only 13 patients were diagnosed with chronic pancreatitis. When the DP was performed for pancreatic tumor, the cumulative incidence was $25.7 \%$ $(112 / 373)$, lower than when DP was performed for chronic pancreatitis $(38.46 \%, 5 / 13)$. Nevertheless, this difference was not statistically significant $(p=0.318)$, probably because the sample of patients with chronic pancreatitis was small.

Resected pancreas ratio or volume was identified as a significant predictor for post-DP DM in several previous studies. $^{791122-24}$ However, the methods used to calculate resected pancreas volume ratio by previous studies 791122 were complicated. These methods required patients to undergo both preoperative and postoperative contrastenhanced CT in which the parenchyma of the pancreas was outlined on each CT slice, with the exclusion of bile ducts, splenic vessels, portal veins, dilated pancreatic ducts, and tumors. In the present study, we used the length of resected pancreas as a predictive parameter for the risk of postoperative NODM. This parameter was more accessible and convenient to calculate through the gross examination of the resected specimen (online supplemental figure 1). Furthermore, length of resected pancreas was identified as an independent risk factor for NODM.

The current findings indicated that patients who received DP with splenectomy had a twofold greater risk of developing postoperative NODM, compared with those who received spleen-preserving DP. Previous clinical observations reported similar association between splenectomy and glucose intolerance or diabetes among patients undergoing splenectomy for trauma ${ }^{25} 26$ or severe thalassemia. ${ }^{27}$ Nevertheless, to our knowledge, this was the first large cohort study validating the association between splenectomy and the development of NODM after DP.

The spleen is thought to harbor pancreatic stem cells, ${ }^{28}$ as cells within the spleen demonstrate close inter-relationships with stem cells during embryonic development. $^{3031}$ The splenic mesenchyme is reported to bud off from the pancreatic mesenchyme during early development. ${ }^{32}$ This close relationship between cell types was also seen in a study that used PTF1-p48 (pancreasspecific transcription factor $1 \mathrm{a}$, also known as Ptfla) gene knockout mice. ${ }^{33}$ Although these mice were born without an exocrine pancreas, functional islets were found in the spleen and these animals showed normoglycemia. Other rodent studies revealed that splenocytes could enhance the neogenesis of pancreatic $\beta$-islet secretory cells ${ }^{34}$ and protect against obesity-associated insulin resistance. ${ }^{35}$ 
The present study also indicated that higher age, BMI and operative blood loss were independent predictive factors for post-DP NODM. We speculate that the higher incidence of NODM in elder patients may be attributed to the degradation of pancreatic function. Among individuals with increasing BMI, the odds of developing DM in Asians were reported to increase significantly. ${ }^{36}$ Additionally, increasing blood loss during surgery might cause ischemia and edema of remnant pancreas ${ }^{37}$ and directly impair its long-term endocrine function.

As described by Belyaev et $a l^{38}$ patients who postoperatively developed endocrine or exocrine insufficiency suffered more losses in their physical quality of life. Thus, early detection of and intervention for NODM is essential for management of patients after DP. The present study identified independent risk factors for NODM after DP. These findings allow us to select patients with high risk for NODM and design more stringent surveillance and follow-up schedules for them. Early intervention and intensive glucose control have been reported to decrease the risks of major cardiovascular events and death in patients newly diagnosed with diabetes. ${ }^{39}$ Additionally, in patients with impaired glucose tolerance, the early introduction of antidiabetic agents has been reported to diminish the development of overt diabetes. ${ }^{40}$

Several limitations should be considered when interpreting these results. First, disease profile in this cohort of patients was not included in malignant diseases, although several studies reported the association between DM and pancreatic cancer. ${ }^{41-44}$ However, adenocarcinoma of the body and tail of the pancreas usually associated with a poor overall survival, which is not adequate for the observation of NODM development. Second, many patients received DM treatment outside of our institution. Consequently, detailed information on the therapeutic regimen of NODM was not available for a substantial number of patients. Third, our objectives were limited to Asian patients. Whether these results can be generalized to western countries need further study to validation.

Acknowledgements We thank all the staff from Department of General Surgery, Peking Union Medical College Hospital, Peking Union Medical College and Chinese Academy of Medical Sciences of China.

Contributors MD, CX, and NS analyzed the data, wrote and revised the manuscript. MD designed the study and supervised the whole project. CX, NS, SW, and GW collected, analyzed and discussed the data. MD, QL, TZ, GC, WW, JG and ZL performed the operations, supervised the project, analyzed and discussed the data, and revised the manuscript. All the authors approved to submit the final manuscript for publication consideration.

Funding This study was supported by the project of application and promotion of capital special clinical research from Beijing Municipal Science and Technology Commission (Z171100001017017018) and the Guangdong Medical Science and Technology Research Fund (A2018128).

Competing interests None declared.

Patient consent for publication Not required.

Ethics approval The study protocol was approved by the institutional review board and registered at the US National Institutes of Health (https://www.clinicaltrials.gov/).

Provenance and peer review Not commissioned; externally peer reviewed.
Data availability statement Data are available upon reasonable request. All data generated or used during the study are available from the corresponding author by request.

Supplemental material This content has been supplied by the author(s). It has not been vetted by BMJ Publishing Group Limited (BMJ) and may not have been peer-reviewed. Any opinions or recommendations discussed are solely those of the author(s) and are not endorsed by BMJ. BMJ disclaims all liability and responsibility arising from any reliance placed on the content. Where the content includes any translated material, BMJ does not warrant the accuracy and reliability of the translations (including but not limited to local regulations, clinical guidelines, terminology, drug names and drug dosages), and is not responsible for any error and/or omissions arising from translation and adaptation or otherwise.

Open access This is an open access article distributed in accordance with the Creative Commons Attribution Non Commercial (CC BY-NC 4.0) license, which permits others to distribute, remix, adapt, build upon this work non-commercially, and license their derivative works on different terms, provided the original work is properly cited, appropriate credit is given, any changes made indicated, and the use is non-commercial. See: http://creativecommons.org/licenses/by-nc/4.0/.

ORCID iD

Menghua Dai http://orcid.org/0000-0002-7273-6282

\section{REFERENCES}

1 Sachs T, Pratt WB, Callery MP, et al. The incidental asymptomatic pancreatic lesion: nuisance or threat? J Gastrointest Surg 2009:13:405-15.

2 American Diabetes Association. Diagnosis and classification of diabetes mellitus. Diabetes Care 2014;37:S81-90.

3 Townsend CM. Sabiston textbook of surgery: the biological basis of modern surgical practice. Canada: Elsevier Saunders, 2012.

4 King J, Kazanjian K, Matsumoto J, et al. Distal pancreatectomy: incidence of postoperative diabetes. J Gastrointest Surg 2008;12:1548-53.

5 Falconi M, Mantovani W, Crippa S, et al. Pancreatic insufficiency after different resections for benign tumours. Br J Surg 2008;95:85-91.

6 Shikano T, Nakao A, Kodera Y, et al. Middle pancreatectomy: safety and long-term results. Surgery 2010;147:21-9.

7 Kang JS, Jang J-Y, Kang MJ, et al. Endocrine function impairment after distal pancreatectomy: incidence and related factors. World $\mathrm{J}$ Surg 2016;40:440-6.

8 DiNorcia J, Ahmed L, Lee MK, et al. Better preservation of endocrine function after central versus distal pancreatectomy for mid-gland lesions. Surgery 2010;148:1247-56.

9 Kwon JH, Kim SC, Shim IK, et al. Factors affecting the development of diabetes mellitus after pancreatic resection. Pancreas 2015;44:1296-303.

10 Burkhart RA, Gerber SM, Tholey RM, et al. Incidence and severity of pancreatogenic diabetes after pancreatic resection. $J$ Gastrointest Surg 2015;19:217-25.

11 Shirakawa S, Matsumoto I, Toyama H, et al. Pancreatic volumetric assessment as a predictor of new-onset diabetes following distal pancreatectomy. J Gastrointest Surg 2012;16:2212-9.

12 Crippa S, Bassi C, Warshaw AL, et al. Middle pancreatectomy: indications, short- and long-term operative outcomes. Ann Surg 2007;246:69-76.

13 American Diabetes Association. Standards of medical care in diabetes - 2017. Diabetes Care 2017;40:1-142.

14 Warshaw AL. Conservation of the spleen with distal pancreatectomy. Arch Surg 1988;123:550-3.

15 Kimura W, Inoue T, Futakawa N, et al. Spleen-Preserving distal pancreatectomy with conservation of the splenic artery and vein. Surgery 1996;120:885-90.

16 Dai M-H, Shi N, Xing C, et al. Splenic preservation in laparoscopic distal pancreatectomy. Br J Surg 2017;104:452-62.

17 Dindo D, Demartines N, Clavien P-A. Classification of surgical complications. Ann Surg 2004;240:205-13.

18 Bassi C, Marchegiani G, Dervenis C, et al. The 2016 update of the International Study Group (ISGPS) definition and grading of postoperative pancreatic fistula: 11 years after. Surgery 2017;161:584-91.

19 Hirata K, Nakata B, Amano R, et al. Predictive factors for change of diabetes mellitus status after pancreatectomy in preoperative diabetic and nondiabetic patients. J Gastrointest Surg 2014;18:1597-603. 
20 Lim P-W, Dinh KH, Sullivan M, et al. Thirty-day outcomes underestimate endocrine and exocrine insufficiency after pancreatic resection. HPB 2016;18:360-6.

21 De Bruijn KM, van Eijck $\mathrm{CH}$. New-Onset diabetes after distal pancreatectomy: a systematic review. Ann Surg 2015;261:854-61.

22 Yun SP, Seo H-l, Kim S, et al. Does the pancreatic volume reduction rate using serial computed tomographic volumetry predict new onset diabetes after pancreaticoduodenectomy? Medicine 2017;96:e6491.

23 Kendall DM, Sutherland DER, Najarian JS, et al. Effects of hemipancreatectomy on insulin secretion and glucose tolerance in healthy humans. N Engl J Med 1990;322:898-903.

24 Sakata N, Egawa S, Rikiyama T, et al. Computed tomography reflected endocrine function of the pancreas. J Gastrointest Surg 2011;15:525-32.

25 Ley EJ, Singer MB, Clond MA, et al. Long-Term effect of trauma splenectomy on blood glucose. J Surg Res 2012;177:152-6.

26 SC W, CY F, Muo CH, et al. Splenectomy in trauma patients is associated with an increased risk of postoperative type II diabetes: a nationwide population-based study. Am J Surg 2014;208:811-6.

27 Lee BW, Tan SH, Lee WK, et al. Glucose tolerance test and insulin levels in children with transfusion-dependent thalassaemia. Ann Trop Paediatr 1985;5:215-8.

28 Dieguez-Acuna FJ, Gygi SP, Davis M, et al. Splenectomy: a new treatment option for all tumors expressing Hox-11 and a means to test the stem cell hypothesis of cancer in humans. Leukemia 2007;21:2192-4.

29 Lonyai A, Kodama S, Burger D, et al. The promise of Hox11+ stem cells of the spleen for treating autoimmune diseases. Horm Metab Res 2008;40:137-46.

30 Kodama S, Davis M, Faustman DL. Diabetes and stem cell researchers turn to the lowly spleen. Science of Aging Knowledge Environment 2005;2005:pe2.

31 Hörnblad A, Eriksson AU, Sock E, et al. Impaired spleen formation perturbs morphogenesis of the gastric lobe of the pancreas. PLoS One 2011;6:e21753.

32 Asayesh A. Spleen versus pancreas: strict control of organ interrelationship revealed by analyses of Bapx1-/- mice. Genes Dev 2006;20:2208-13.
33 Krapp A, Knofler M, Ledermann B, et al. The bHLH protein PTF1-P48 is essential for the formation of the exocrine and the correct spatial organization of the endocrine pancreas. Genes Dev 1998;12:3752-63.

34 Park S, Hong SM, Ahn ILS. Can splenocytes enhance pancreatic $\beta$-cell function and mass in $90 \%$ pancreatectomized rats fed a high fat diet? Life Sci 2009;84:358-63.

35 Wu L, Parekh VV, Hsiao J, et al. Spleen supports a pool of innate-like $B$ cells in white adipose tissue that protects against obesity-associated insulin resistance. Proc Natl Acad Sci U S A 2014;111:E4638-47.

36 Boffetta P, McLerran D, Chen Y, et al. Body mass index and diabetes in Asia: a cross-sectional pooled analysis of 900,000 individuals in the Asia cohort Consortium. PLoS One 2011;6:e19930.

37 Callery MP, Pratt WB, Kent TS, et al. A prospectively validated clinical risk score accurately predicts pancreatic fistula after pancreatoduodenectomy. J Am Coll Surg 2013;216:1-14.

38 Belyaev O, Herzog T, Chromik AM, et al. Early and late postoperative changes in the quality of life after pancreatic surgery. Langenbecks Arch Surg 2013;398:547-55.

39 Holman RR, Paul SK, Bethel MA, et al. 10-Year follow-up of intensive glucose control in type 2 diabetes. N Engl J Med 2008;359:1577-89.

40 Kawamori R, Tajima N, Iwamoto Y, et al. Voglibose for prevention of type 2 diabetes mellitus: a randomised, double-blind trial in Japanese individuals with impaired glucose tolerance. The Lancet 2009;373:1607-14

41 Li D, Yeung S-CJ, Hassan MM, et al. Antidiabetic therapies affect risk of pancreatic cancer. Gastroenterology 2009;137:482-8.

42 Magruder JT, Elahi D, Andersen DK. Diabetes and pancreatic cancer: chicken or egg? Pancreas 2011;40:339-51.

43 Bosetti C, Rosato V, Li D, et al. Diabetes, antidiabetic medications, and pancreatic cancer risk: an analysis from the International pancreatic cancer case-control Consortium. Annals of Oncology 2014;25:2065-72.

44 Lu Y, Rodríguez LAG, Malgerud L, et al. New-Onset type 2 diabetes, elevated $\mathrm{HbA} 1 \mathrm{c}$, anti-diabetic medications, and risk of pancreatic cancer. Br J Cancer 2015;113:1607-14. 